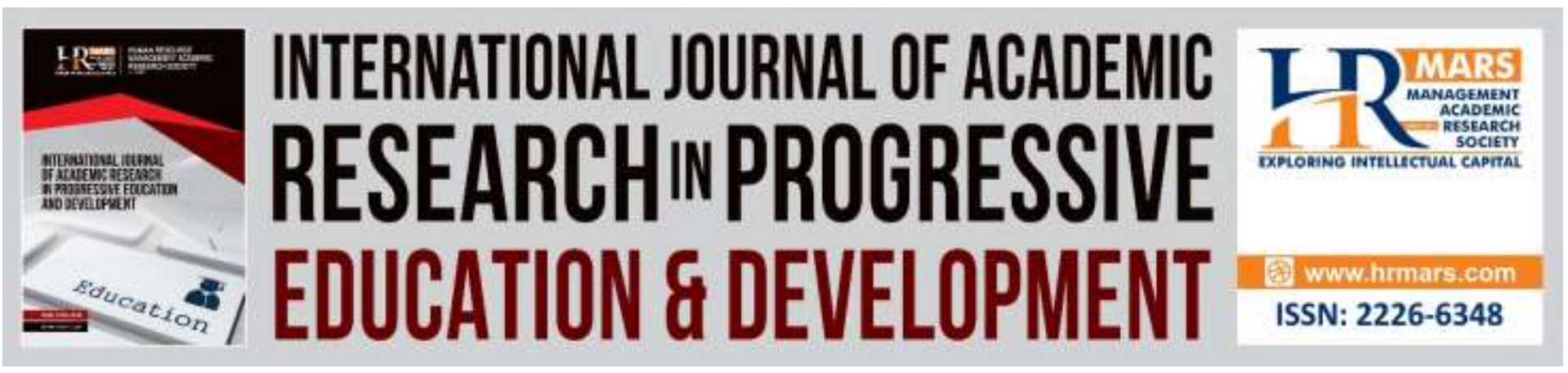

\title{
The Development Of Preschools' Higher Order Thinking Skills (HOTs) Teaching Model towards Improving the Quality of Teaching
}

Suppiah Nachiappan, Rosma Osman, Abdul Halim Masnan, Mazlina Che Mustafa, Hashimah Hussein \& Sandra Suffian

To Link this Article: http://dx.doi.org/10.6007/IJARPED/v8-i2/5601

DOI: $10.6007 /$ IJARPED/v8-i2/5601

Received: 29 Jan 2019, Revised: 21 Feb 2019, Accepted: 11 March 2019

Published Online: 18 March 2019

In-Text Citation: (Nachiappan et al., 2019)

To Cite this Article: Nachiappan, S., Osman, R., Masnan, A. H., Mustafa, M. C., Hussein, H., \& Suffian, S. (2019). The Development Of Preschools' Higher Order Thinking Skills (HOTs) Teaching Model towards Improving the Quality of Teaching. International Journal of Academic Research in Progressive Education and Development, 8(2), 39-53.

Copyright: (c) 2019 The Author(s)

Published by Human Resource Management Academic Research Society (www.hrmars.com)

This article is published under the Creative Commons Attribution (CC BY 4.0) license. Anyone may reproduce, distribute, translate and create derivative works of this article (for both commercial and non-commercial purposes), subject to full attribution to the original publication and authors. The full terms of this license may be seen at: http://creativecommons.org/licences/by/4.0/legalcode

Vol. 8(2) 2019, Pg. 39 - 53

http://hrmars.com/index.php/pages/detail/IJARPED

JOURNAL HOMEPAGE

Full Terms \& Conditions of access and use can be found at http://hrmars.com/index.php/pages/detail/publication-ethics 


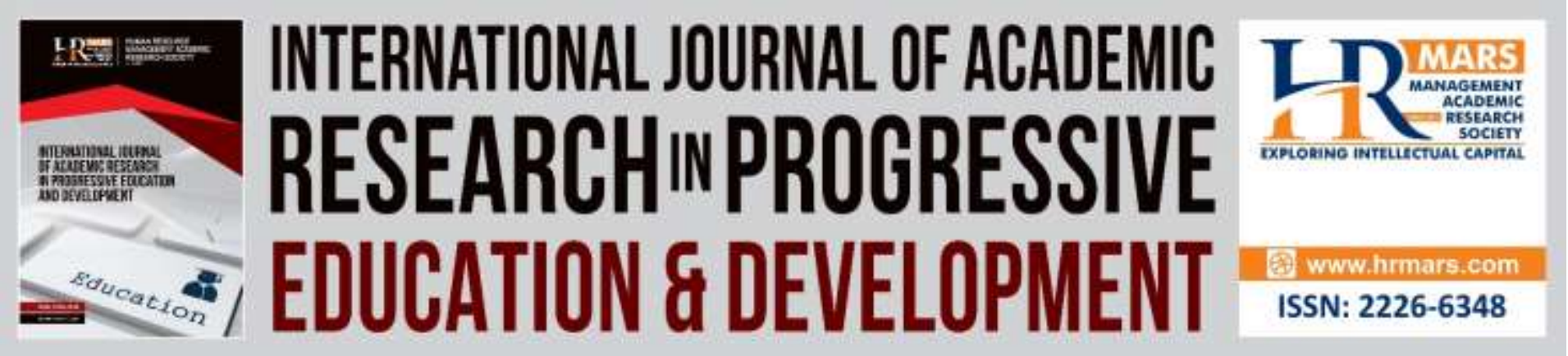

\title{
The Development Of Preschools' Higher Order Thinking Skills (HOTs) Teaching Model towards Improving the Quality of Teaching
}

\author{
Suppiah Nachiappan, Rosma Osman, Abdul Halim Masnan, \\ Mazlina Che Mustafa, Hashimah Hussein \& Sandra Suffian \\ Faculty of Human Development, Sultan Idris Education University
}

\begin{abstract}
The purpose of this study is to develop a preschools' higher order thinking skills (HOTS) teaching model. Some important aspects are also studied namely, the level of preschool teacher's thinking, the preschool teacher's view of the role played by the authorities, the needs of preschool teachers in implementing HOTS and the daily teaching practice of preschool teachers. The mixed method approach is used in this study. The quantitative study was analyzed using the SPSS version 23 software while the qualitative study was analyzed using the Hermeneutic method that was interpretation of text to metatext. A total of 125 preschool teachers from all over Perak state were involved in quantitative data collection using questionnaires. Meanwhile, 30 preschool teachers from three districts, Larut Matang Selama, Kuala Kangsar and Kinta Utara were involved in the collection of qualitative data using observation, interview form and daily lesson plan document analysis. The findings show that the implementation of HOTS at preschool level is still at a moderate level as there are still less skilled teachers in implementing HOTS during the teaching and learning process. In addition, the role of the authorities is still at the beginning because not all preschool teachers have the opportunity to attend courses, trainings, seminars related to the implementation of HOTS especially the teachers who teach in the rural schools. The implication of this study is that authorities such as Ministry of Education, Perak State Education Department, District Education Office and principals need to strengthen the implementation of HOTS through the provision of courses, trainings and seminars as well as improving teachers' needs for teaching and learning processes such as providing teaching aids as well as conducive learning space. In addition, with a preschool HOTS modeling book guide, it can be used as a guide to teachers in the implementation of HOTS in preschool.
\end{abstract}

Keywords: Preschool, Teaching Model, Hots, National Preschool Standard Curriculum, Hermeneutic Method 
INTERNATIONAL JOURNAL OF ACADEMIC RESEARCH IN PROGRESSIVE EDUCATION AND

DEVELOPMENT

Vol. 8, No. 2, 2019, E-ISSN: 2226-6348 @ 2019 HRMARS

\section{Introduction}

A transformation has been made on education in Malaysia through the Malaysian Education Development Plan (PPPM) 2013-2025. This change is done extensively involving preschool education to higher education by placing Higher Order Thinking Skills (HOTS) as one of the key areas emphasized in teaching. According to Alison (2015), higher order thinking skill is considered as one of the lifelong learning processes.

This requirement is in line with the economic boom, technological change and job marketability in the global economic market. In fact, high quality human capital in education is a major milestone in the country's education system. Hence, in 2015 all schools will implement 21st century learning aimed at enhancing and cultivating thinking skills towards innovative students as contained in the Malaysia Education Blueprint 2013-2025 (Ministry of Education Malaysia, 2013).

Therefore, preschool education is also changing through the Curriculum and Assessment Standard Document (DSKP) 2017 by incorporating HOTS as one of the main focus areas in teaching (Ministry of Education Malaysia, 2016). Among the things emphasized in the formulation of KSPK is the Higher Order Thinking Skills (HOTS) which are explicitly stated in the Writing Standard. Teachers need to translate the Learning Standard in teaching and learning in the classroom with an emphasis on HOTS.

\section{Problem Statement}

However, this is a challenge for preschool teachers because HOTS is the ability to apply knowledge, skills and values in making reasoning and reflection to solve problems, make decisions, innovate and create something. HOTS covers critical thinking, creative thinking skills and thinking strategies (Ministry of Education Malaysia, 2016). In fact, preschool education also requires HOTS to prepare for the challenge and the mastery of family planning at primary school.

The implementation of HOTS in education today is facing various issues. Among them, A. Rahman, Jamaludin and Zamri (2015) stated that most teachers did not emphasize the thinking skills of the students in their teaching. Teachers are more focused on trying to achieve their teaching objectives and complete their syllabus. According to Nor, Adibah, Mahzan and Aliza (2012), there are some reasons why thinking skills are not emphasized, among which some teachers are with opinion that students should first master the facts and concepts of a subject before can be encouraged to think.

In fact, since the implementation of HOTS as a whole in 2014 , less studies have been linked to empowering HOTS at preschool level. This raises questions about whether HOTS has been implemented in preschools and how are the teaching and learning of preschools in empowering HOTS? Recent studies have focused on the implementation of HOTS at primary level (Nooriza \& Effandi, 2015; A. Rahman, Jamaludin \& Zamri, 2015), at the secondary school level (Suhaimi, Baharuddin, Hasnah, Norasykin \& Zaleha, 2014) institutions of higher learning (Yee, Jailani, Widad, Razali \& Tee, 2015). 
Based on these issues, the researcher feels that the HOTS Teaching Model is a form of resolution to these issues. This is because the development of the Teaching Model should carefully and thoroughly examine the developmental elements of the teaching model, i) focus, ii) syntax, iii) response principle, iv) social system, and v) support system (Joyce, Weil \& Calhoun, 2008). This model can be used as a guideline for teachers and related parties to foster HOTS through teaching and learning in schools.

\section{Literature Review}

According to Suppiah (2015), the National Preschool Standard Curriculum (KSPK) is an established policy to ensure that kindergarten operators make the subject frame according to the standards issued by the government. In other words, National Preschool Standard Curriculum (KSPK) is a guide for all parties involved directly or indirectly in the process of teaching and learning at preschool level.

A comprehensive transformation of education from preschool to higher education through the Malaysia Education Blueprint 2013-2025 is a long-term strategic plan aimed at enhancing the quality of education nationwide within 13 years (Ministry of Education Malaysia, 2013). The Higher Order Thinking Skills which are emphasized as one of the factors in determining the success of education transformation as outlined in Malaysia Education Development Plan 2013-2025 (PPPM). Higher Order Thinking Skills (HOTS) is the ability to apply knowledge, skills and values in making reasoning and reflection to solve problems, make decisions, innovate and create something (Ministry of Education Malaysia, 2014).

According to Chew Feng Pong and Shashipriya (2014), thinking skills are applied to students through high-level questions, activities that promote thinking and problem solving as well as teaching methods that can drive towards improving thinking skills.

In the context of preschool education, there is no further study in the country that leads to the adoption of HOTS among preschoolers. Early childhood education provides unlimited opportunities in developing children's thinking skills (Birbili, 2013). The results of the study of Birbili (2013), found that the effort to enrich the experience and to stimulate the children's thinking skills by teachers has been reduced. This is because preschoolers find it difficult to ask open-ended questions and attract children to higher thinking.

\section{Research Objectives}

Generally, this study was conducted to develop a preschool higher order thinking skills teaching model. In particular, some aspects are emphasized as the objective of the study:

i. Identify teachers' thinking style to implement HOTS in preschool.

ii. Analyze the teacher's views on the role of the parties involved in the implementation of HOTS in preschool.

iii. Analyze teachers' needs in implementing HOTS in preschool.

iv. Developing a Higher Order Thinking Skills Teaching Model for Preschool. 
INTERNATIONAL JOURNAL OF ACADEMIC RESEARCH IN PROGRESSIVE EDUCATION AND DEVELOPMENT

Vol. 8, No. 2, 2019, E-ISSN: 2226-6348 @ 2019 HRMARS

\section{Research Questions}

The study was conducted to answer the following questions:

i. What is the level of teacher thinking style to implement HOTS in preschool?

ii. What is the teacher's view of the role played by the parties involved in the implementation of HOTS in preschool?

iii. What are the needs of teachers in implementing HOTS in preschool?

iv. What are the daily teaching practices of teachers in preschool?

v. What elements can be synthesized in developing the Preschool HOTS Teaching Model?

\section{Research Methodology}

This study uses a mixed-method, where the instrument of the study consists of questionnaires, observation forms and interviews. This study involved 125 preschool teachers around Perak for questionnaire data. While the methods of observation and interviews were conducted in 30 preschools from three districts, namely, North Kinta, Ipoh Larut Matang and Selama (LMS) that involved 30 preschool teachers.

Quantitative data were analyzed using SPSS software while qualitative data obtained were interpreted and analyzed using Hermeneutics method. Researchers use the Hermeneutics method of emphasizing text as a study material and to understand the rational features of human thought and the purpose it contains. Shaped interpretive analysis and the main focus is to make interpretation and the interpretation of what is produced by the human implications of meaning (Loganathan, 1992). The research data is known as text and then the last interpretation text is known as metatext.

\section{Results}

A. Quantitative Findings

The following is a table for the analysis of the findings of the questionnaire to answer the question 1. 
INTERNATIONAL JOURNAL OF ACADEMIC RESEARCH IN PROGRESSIVE EDUCATION AND DEVELOPMENT

Vol. 8, No. 2, 2019, E-ISSN: 2226-6348 @ 2019 HRMARS

Table 1: Level of Teacher's Thinking Style

\begin{tabular}{clcc}
\hline No & \multicolumn{1}{c}{ Item } & \multicolumn{2}{c}{ Percentage of respondents } \\
& & Agree & (\%) \\
& & 97.6 & 2.4 \\
\hline 1. & Curiosity & 69.6 & 30.4 \\
2. & Open-mindedness & 94.1 & 5.9 \\
3. & Systematic & 86.1 & 13.9 \\
4. & Analitic & 69.6 & 30.4 \\
5. & Finding the truth & 87.7 & 12.3 \\
6. & Self confidence in Thinking Skills & 74.4 & 25.6 \\
7. & Maturity & & \\
\hline
\end{tabular}

Based on the findings of the questionnaires, the researcher found that the level of teacher thinking style showed a positive result as preschool teachers were open minded in implementing HOTS at preschool level. Preschool teachers also adopt systematic, analytical, curiosity thinking, have a level of self-confidence in implementing HOTS and have mature thinking.

B. Qualitative Findings

The qualitative findings were to answer the study questions $2,3,4$ and 5.

Research Questions 2: The teacher's view of the role played by the parties involved in the implementation of HOTS in preschool

1. The Interpretation of the Role of the Ministry of Education Malaysia in Implementing HOTS at the Preschool Level by Using Hermeneutics Method

The results of the teacher's answers were analyzed by districts and it was found that teachers' answers were different in each district. Based on the answers of teachers in the districts of Larut Matang and Selama, it is found that the Ministry of Education Malaysia plays a role in implementing HOTS at preschool. However, teachers feel that the disclosure provided by the ministry is very poor. Detailed disclosure of the HOTS implementation should be provided by the Ministry of Education to ensure that teachers are able to implement it at the preschool level.

On the other hand, teachers in Kuala Kangsar and North Kinta districts feel that the Ministry of Education plays an important role in providing exposure to implementing HOTS at primary level. Teachers also feel that KPM has provided exposure and HOTS implementation courses to teachers. There are also teachers who suggest that Ministry of Education should train District Education Office officers to conduct HOTS implementation courses at preschool level to teachers.

Overall, it is found that the Ministry of Education plays an important role in implementing HOTS at preschool level. The main role that Ministry of Education needs to play is to expose 
INTERNATIONAL JOURNAL OF ACADEMIC RESEARCH IN PROGRESSIVE EDUCATION AND DEVELOPMENT

Vol. 8, No. 2, 2019, E-ISSN: 2226-6348 @ 2019 HRMARS

teachers to the HOTS implementation and to monitor the implementation of HOTS at preschool level. The MoE can also appoint an easy-to-use District Education Office officer so that teachers can learn more about the implementation of HOTS at preschool level.

2. The Interpretation of Roles of Perak State Education Department and District Education Office in Implementing HOTS at Preschool Level by Using Hermeneutics Method

Based on the analysis done, the teachers in the districts of Larut Matang and Selama stated that the Perak State Education Department and District Education Office have provided exposure on the implementation of HOTS in preschool through courses and workshops. However, teachers hope that more workshops focused on HOTS in preschool will be carried out. This is because earlier workshops focus on the mainstream rather than preschool.

Meanwhile, teachers in the district of Kuala Kangsar stated that the Perak State Education Department and District Education Office play an important role in conducting training and courses to implement HOTS at preschool level. Although the courses and training are carried out by the Perak State Education Department and District Education Office, it is still inadequate and does not fully focus on the implementation of HOTS at preschool level. Teachers also suggested that the District Education Office provide expert instructional services to train preschool teachers in the implementation of HOTS at preschool level. Teachers in the North Kinta district also explained that the Perak State Education Department and District Education Office held courses and training for HOTS implementation to teachers but were less focused on the implementation of HOTS at preschool level. Preschool teachers are forced to use their own creativity to implement HOTS at preschool level.

It can therefore be concluded that the Perak State Education Department and the District Education Office play a role in the implementation of HOTS at the preschool level but are not fully implemented. Teachers' opinions should be considered in order to improve the effectiveness of HOTS implementation at preschool level.

3. The Interpretation of the Role of the Headmaster in Implementing HOTS at the Preschool Level by Using Hermeneutics Method

Teachers in all three districts stated that the headmaster at each school played a role in the implementation of HOTS at the preschool level. Teachers in the districts of Larut Matang and Selama stated that the headmaster always provided assistance and support to teachers to implement HOTS at preschool level. It is noted that the headmaster always disseminates information on the implementation of HOTS to teachers through email, pamphlets and information sharing as well as monitoring teachers either during learning and facilitating or through daily review of lesson plans.

In addition, teachers in the Kuala Kangsar district also stated that the headmaster always supported them to implement HOTS in the classroom. Big teachers in this area provide guidance 
INTERNATIONAL JOURNAL OF ACADEMIC RESEARCH IN PROGRESSIVE EDUCATION AND DEVELOPMENT

Vol. 8, No. 2, 2019, E-ISSN: 2226-6348 @ 2019 HRMARS

to preschool teachers and ensure that they implement HOTS at preschool level. Teachers in the North Kinta district stated that their headmaster also encouraged the implementation of HOTS at preschool level. Big teachers are always communicating information on the implementation of HOTS to teachers through Training in Service (LADAP).

In conclusion, it is found that the headmaster plays their role effectively in various ways. The headmaster not only delivers instructions and information on the implementation of HOTS to preschool teachers, but even train and monitor them from time to time in various ways. The role played by the headmistress must ensure that the implementation of HOTS at preschool level can run smoothly.

\section{Research Questions 3: Teachers Needs in Implementing HOTS in Preschool}

1. The Interpretation of the Teacher Needs for HOTS Teaching in Preschool by Using Hermeneutics Method

Larut Matang and Selama district respondents stated that the need for teachers for HOTS teaching was given a more detailed course, workshop or briefing on HOTS teaching, teaching aids that could stimulate student thinking, material preparation, planned questions and related HOTS form. In addition, ICT facilities are also very much needed such as laptops, computers and projectors for each class.

The main requirements needed by Kuala Kangsar district respondents are exposure on HOTS approach and activities that are appropriate to the level of student development, internet facilities, projector LCDs and speakers. Respondents also noted that attractive teaching and learning materials and multimedia materials should be provided adequately.

North Kinta district respondents stated that their main requirement was a special workshop for HOTS preschool, the needs of Daily Lesson Plan materials namely the latest teaching aids such as laptops and internet facilities. In addition, respondents also need more courses / exercises / demonstrations to improve the knowledge of teachers in implementing HOTS.

\section{Research Questions 4: Teacher Daily Teaching Practice at Preschool}

The following is a description of the observation of teachers' daily teaching practices for all three districts namely Larut Matang \& Selama (LMS), Kuala Kangsar and North Kinta.

i. Teacher Daily Teaching Practice for Larut Matang and Selama

The overall findings of observation find that the preschool teacher of Larut Matang \& Selama district has implemented HOTS in teaching and learning at preschool. However, only a handful of teachers have skills on HOTS. This is because, there are still some teachers who lack the exposure of HOTS skills. 
In addition, the teacher also states the HOTS element in the provision of Daily Lesson Plan. Among the HOTS elements expressed by teachers in the preparation of Daily Lesson pLan is to compare, classify, generate ideas and illustrate. Teachers also carry out induction sets before beginning teaching and learning sessions. Based on observation of teachers, teachers are also creative in implementing induction sets. Among them, respondents 3 closed the eyes and then asked the pupil to guess the fruit by touch and smell. Through the methods used by the teacher, pupils' learning will become more fun because it results in a student's curiosity about something. The rest, teachers are more likely to answer questions with students about past lessons and introduce teaching topics on that day.

Meanwhile, the teaching strategy used by the teacher is to focus on the students, the teacher provides activities and the students will perform the activities in groups. Among the group activities teachers provide, such as, solving puzzles, classifying local and foreign fruits, making fruit roes and pupils do the process of making cup corn. Through the teaching strategy, students' thinking will be stimulated because the activities provided will encourage students to think strategies and ways to solve the problems they are facing.

In closing to teaching and learning, teachers are also involved in reflection by asking students how to complete the assignment. Teachers will also be able to answer questions with students about the topics they have learned to reinforce their understanding of the topic.

\section{ii. Teacher Daily Teaching Practice for Kuala Kangsar District}

The researcher found that Kuala Kangsar district preschool teacher did not mention the HOTS element in preparing the Daily Lesson Plan. The existing HOTS element is simply generating ideas, collecting and welding. In terms of the implementation of the induction set, teachers are more using IT technology such as playing a song using a laptop, playing a sound and then asking students to guess the sound and also watch a video clip.

Meanwhile, the teaching strategies used by teachers are also creative such as having a buying and selling simulation with pupils to ensure students understand the right concept of money. Teachers also carry out experiments by putting specific objects into the water and asking the pupils to guess whether the object will sink or arise. Teachers also use the method of cynicism with students throughout the teaching and learning sessions.

Teachers also use teaching aids that are relevant to the needs of the topics learned by the students. Among the worksheet works provided by teachers are writing, cutting, colouring, pasting and typing answers using a teacher's laptop. 
iii. Teacher Daily Teaching Practice for North Kinta District

The researcher found that only three Kinta Utara preschool teachers have stated the HOTS element in preparing the Daily Lesson Plan. Among the HOTS elements expressed are, classify, predict, connect, generate ideas and solve problems. In terms of the implementation of the induction set, teachers are more likely to use learning methods that can trick pupils' thinking like making tricks, reading puzzles, playing sirens and displaying some picture card pieces for pupils.

While the teaching strategy used by the teacher is also creative as the student conducts a buying and selling simulation using the specimen provided, the pupil runs the experiment and sinks while predicting which object will arise or sink, the pupil doing the activity of finding a landmark in the classroom as well as the pupil explore and identify fruit types around the outside of the classroom.

Teachers also use teaching aids that are relevant to the needs of the topics learned by the students. However, researchers did not see any use of I-Think maps throughout the teaching and learning process. Among the teaching aids often used by teachers are laptops, pictorial cards, word cards and worksheets.

\section{Research Questions 5: Synthesized Elements in Developing Preschool HOTS Teaching Model}

Among the elements that can be synthesized in developing the HOTS teaching model is the preparation of objectives, selection of content, content organization, selection of learning experiences and the preparation of learning activities. To facilitate teachers to implement HOTS in teaching and learning, researchers have adapted the Taba teaching model in building the HOTS teaching model in preschools as shown in Figure 1. 


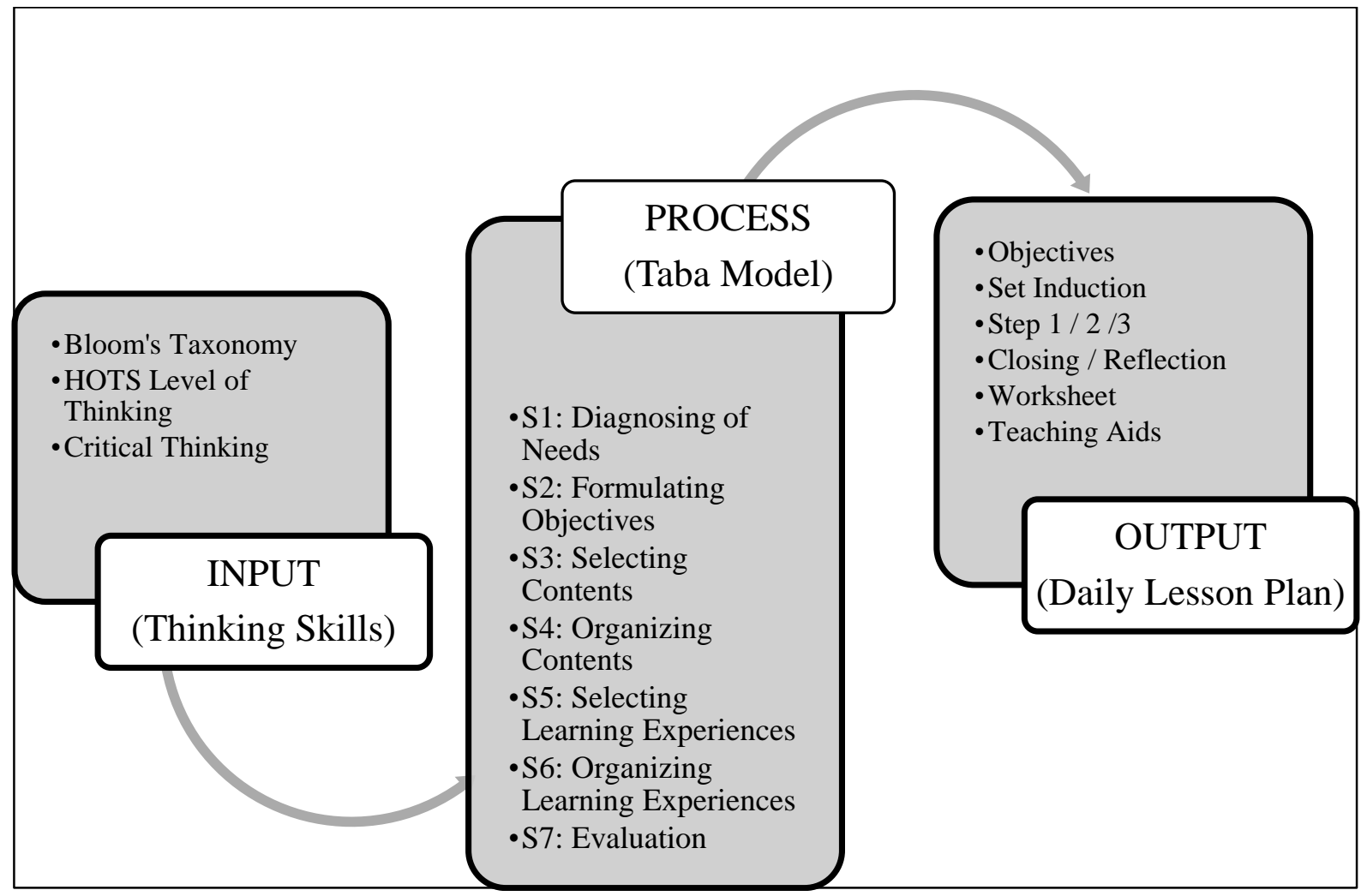

Figure 1: Proposed Preschool HOTS Teaching Model

\section{Discussions}

The findings of this study will focus on the findings associated with previous theories and studies by looking at the similarities and differences.

A. The level of teacher-thinking style to implement HOTS in preschool

The findings of the questionnaire showed that teachers were very curious, open-minded, systematic, analyzed, looking for reality, confident in their thinking skills and mature. This style of thinking allows them to cultivate higher thinking skills among preschoolers.

This finding is supported by a study conducted by Norsita and Zainal (2014) aimed at seeing interactions among teachers and pupils in the application of creative thinking children found that teachers' attitude plays an important role in determining preparation, preparation of emotional material and teacher emotion that will influence teachers' teaching styles, emotions and children's learning styles. The stimulus will affect the mood and the idea of the teacher to ask questions further nurturing the creative thinking of children. Therefore, the thought style of a teacher is also able to influence their mood when delivering teaching and learning in the classroom.

B. The teacher's view of the role played by the parties involved in the implementation of HOTS in preschool 
Based on the findings, the researcher found that Ministry of Education, Perak State Education Department, District Education Office and principals play an important role in promoting the implementation of HOTS at preschool level. Among the roles played by Ministry of Education, Perak State Education Department and District Education Office are to provide courses and assistance in implementing HOTS, providing guidance on appropriate teaching methods for preschool, providing facilitators to assist schools and teachers in implementing HOTS in preschool through workshops and courses, providing feedback in the form of evaluation of student achievement in the aspect of teaching skills that is the ability of students to make decisions based on reason and logic, monitoring skills and teacher teaching approaches.

Meanwhile, principals provide teachers assistance through email sharing, interviews, brochures and others, conducting periodic observations on teaching and learning preschool teachers through review of teacher's daily lesson plans and encouraging teachers to place at least one HOTS element within the daily teaching and learning, periodic observation and provide appropriate environmental and infrastructure facilities to make teaching and learning processes more effective.

The findings of this study were supported by Nur Athirah and Faridah (2017) in his study which stated that three important elements in applying HOTS elements in preschool education which are knowledge, skills and attitudes. Therefore, in order to ensure that preschool teachers attain that element, Ministry of Education, Perak State Education Department, District Education Office and principals play an important role in helping to improve the knowledge and skills of preschool teachers in implementing HOTS in preschool.

\section{Teachers need to implement HOTS in preschool}

To support the learning process of pupils in teacher class requires a conducive classroom space as well as a classroom layout that is appropriate for HOTS activities. In addition, visual and textual information materials also help to catalyze HOTS. Teachers also exhibit the work of students who are characterized by HOTS for reference to other students.

To meet the demands of the 21st century learning, teachers need to equip themselves with the new knowledge and skills and practices of teaching and learning relevant to 21st century developments and needs such as the skill of handling advanced technology tools used to implement HOTS throughout the teaching and learning process in preschool. The use of technological facilities is also important throughout the teaching and learning process. Among them are, using projector beam, slide show and also television.

The findings were supported by Norsita and Zainal (2014) which stated that teachers' attitude plays an important role in determining preparation, preparation of emotional material and teacher emotion that will influence the teacher's teaching style, emotion and learning styles of children. The stimulants used will also affect the 'mood' and the idea of the teacher to ask the next question to foster the creative thinking of children. 
Before starting teaching and learning, the teacher will first plan the learning objectives that are appropriate to the students' level of thinking. Teachers will place at least one HOTS element in the preparation of the Daily Lesson Plan. Teachers will also plan appropriate teaching and learning activities to generate high-level thinking. In order to promote high-level thinking, the teacher will create a situation to trick pupils' curiosity such as prejudice, provocation or conflict that is unexpected. Teachers also use the I-Think map as an effective thinking tool and according to the student's cognitive level. Proper educational resources also help in implementing HOTS in preschool teaching and learning such as video, audio, internet and newspaper clippings.

The findings of this study are supported by Norsiah and Norfarahin (2015) that the learning environment such as classroom, friend and teacher creativity in facilitators and external resources is a critical factor for the development of high-level thinking. Teachers apply the method of assistance, questioning and problem solving to all children in the classroom through classroom activities and daily conversations. Questions asked during activities to find out the level of understanding and concept in the minds of children.

\section{E. Elements that can be synthesized in the HOTS teaching model}

Among the elements that need to be seen in developing HOTS preschool model is, the objective of Daily Lesson Plan content provided by teachers, the HOTS element that exists in the preparation of teacher Daily Lesson Plan, HOTS type involved throughout teaching and learning is carried out and teaching and learning activities that can generate high-level thinking of students.

This element is important in developing a preschool HOTS model because through these elements teachers can identify the weaknesses and shortcomings that need to be addressed to create a fun learning environment among preschoolers. Therefore, in order to ensure that the element is achievable by preschool teachers, preparation before starting teaching and learning is the key to the success of teachers in implementing teaching and learning in preschool. The implementation of HOTS on preschool education requires continuous effort to keep the needs of the pupils awake and to ensure that the achievement of preschool education is at a proud level.

\section{Conclusions}

Hopefully this study will open the mindset of educators especially in early childhood education on the importance of implementing HOTS at preschool level in producing a competitive future generation and having global skills that is high-level thinking skills. Teachers play a role in determining their teaching and learning to have HOTS elements that can train high-level thinking of students as early as early childhood. Therefore, as a teacher, especially the preschool teacher needs to be prepared and has a knowledge base on HOTS to be able to apply HOTS elements during teaching and learning. Teachers' knowledge, skills and attitudes are crucial to the successful implementation of HOTS elements in early childhood teaching. Hence, emphasis on the application 
INTERNATIONAL JOURNAL OF ACADEMIC RESEARCH IN PROGRESSIVE EDUCATION AND DEVELOPMENT

Vol. 8, No. 2, 2019, E-ISSN: $2226-6348$ @ 2019 HRMARS

of HOTS at preschool level needs to be strengthened so that teachers and the school do not look lightly on this.

\section{Acknowledgement}

The researcher would like to thank the Sultan Idris University of Education for giving full financial support through the University Research Grant (research code: 2016-0086-106-02) and Human Resource Department of Sultan Idris University of Education. Researchers are also grateful to the Ministry of Education for giving permission to conduct research studies at selected schools.

\section{References}

Haron, A. R., Badusah, J. \& Mahamod, Z. (2015). Kemahiran Berfikir Aras Tinggi (KBAT) Dalam Salak Didik Dengan Elemen Nyanyian Dan Elemen Pantun. Jurnal Pendidikan Bahasa Melayu, 5(1), 53-60.

Alison, J. H. (2015). Phase two: Trends from the online survey: Project Information Literacy's Research Summary Lifelong Learning Study. Seattle: University of Washington.

Birbili, M. (2013). Developing Young Children's Thinking Skills in Greek Early Childhood Classrooms: Curriculum and Practice. Early Child Development and Care, 183(8), 1101-1114.

Chew, F. P., \& Shashipriya, N. (2014). Pelaksanaan Kemahiran Berfikir Kreatif Dan Kritis Dalam Pengajaran Dan Pembelajaran Komsas Di Sekolah Menengah. Jurnal Pendidikan Bahasa Melayu. 4(2), 10-24.

Joyce, B., Weil, M., \& Calhoun, E. (2008). Models of teaching (8th ed.). New York: Pearson.

Loganathan, K. (1992). Hermeneutic analysis of discourse. London: International School of Dravidian Linguistic, India.

Ministry of Education Malaysia. (2013). Malaysia Education Blueprint 2013-2025 (Preschool Education to Post-Secondary Education). Putrajaya: Federal Government Administrative Centre.

Ministry of Education Malaysia. (2014). Element of Higher Order Thinking Skills in Curriculum. Kuala Lumpur: Curriculum Development Division.

Ministry of Education Malaysia. (2016). National Preschool Standard Curriculum. Kuala Lumpur: Curriculum Development Division.

Nooriza, K., \& Effandi, Z. (2015). Integration of Higher Order Thinking Skills in the Teaching and Learning of Mathematics: Teachers' Needs Analysis. Jurnal Pendidikan Matematik, 3(1), 112.

Sharifah, N. P., Nor, A. G., Mohd, M. T., \& Aliza, A. (2012). Keprihatinan Guru Bahasa Melayu dalam Melaksanakan Kemahiran Secara Kritis dan Kreatif. Jurnal Pendidikan Bahasa Melayu, 2(2), 19-31.

Suhaimi, Z., Baharuddin, A., Hasnah, M., Norasykin, M. Z., \& Zaleha, A. (2014). Penerapan Kemahiran Berfikir Aras Tinggi Melalui Model Stesen Rotasi Pelbagai Mod. Konvensyen Antarabangsa Jiwa Pendidik, 11-13 Ogos.

Suppiah, N. (2015). Panduan Pendidikan Awal Kanak-kanak: Teori, Model, Kaedah dan Aktiviti ke Arah Perkembangan Kognisi (2nd ed.). Tanjong Malim: Penerbit Universiti Pendidikan Sultan Idris. 
INTERNATIONAL JOURNAL OF ACADEMIC RESEARCH IN PROGRESSIVE EDUCATION AND DEVELOPMENT

Vol. 8, No. 2, 2019, E-ISSN: 2226-6348@ 2019 HRMARS

Yee, M. H., Jailani, M. Y., Widad, O., Razali, H., \& Tee, T. K. (2015). The Effectiveness of Higher Order Thinking Skills For Generating Idea Among Technical Students. Recent Advances in Educational Technologies, 113-117. 